\title{
Corruption or Correction? : Textual Development in the MT of 1
} Samuel 1

\section{Aejmelaeus, Anneli}

Brill

2012

Aejmelaeus , A 2012 , Corruption or Correction? Textual Development in the MT of 1

Samuel 1. in P A Torijano Morales \& A Piquer Otero (eds), Textual Criticism and Dead Sea

Scrolls Studies in Honour of Julio Trebolle Barrera : Florilegium Complutense. Supplements to the Journal for the Study of Judaism, vol. 157 , Brill , Leiden - Boston , pp. 1-17.

http://hdl.handle.net/10138/217496

unspecified

acceptedVersion

Downloaded from Helda, University of Helsinki institutional repository.

This is an electronic reprint of the original article.

This reprint may differ from the original in pagination and typographic detail.

Please cite the original version. 


\title{
Corruption or Correction?
}

\author{
Textual Development in the MT of 1 Samuel 1
}

Anneli Aejmelaeus

\section{Textual Criticism vs. Textual History}

Textual criticism generally aims at determining the original wording of a given passage in an ancient text, in our case the Hebrew Bible. Text-critical decisions mostly concern variants, alternative readings found in the various textual witnesses of the piece of literature in question, but at times reconstruction of the original reading is also necessary, although some scholars perhaps find it disputable. Textual criticism thus concentrates on small details of the text, mostly one detail at a time.

On the other hand, textual history, which is akin to textual criticism, is more concerned with the overall view of the development of the text at hand and the character of its various witnesses and textual traditions. In order to reach reliable decisions on the details, textual criticism needs all the information there is on the textual history of the text in question, but all text-historical information and the information on the character of the witnesses is based on the evidence of the small details of the text. The two ways of looking at textual evidence are clearly interdependent, which means that caution is needed. A certain overall view tends to turn the decisions on the details toward a direction that further corroborates that very same overall view. For instance, the notion of the MT representing a reliable and very old textual tradition tends to create text-critical decisions that support this notion. It is like the domino effect: dominoes all falling in one direction, one way or the other. How can we make them fall in the right direction?

Of all the rules that have been formulated to assist decision-making in textual criticism, the most worthwhile is the one according to which "the reading that is capable of explaining the emergence of the alternative readings should be regarded as the original." ${ }^{1}$ I would like to go further on this line and maintain that the first and foremost question in textual criticism is not "which one of the readings is the most original?" or "which reading best of all suits the context?", but instead, "what happened to the text?" or "how did the various readings come about?". Even when making decisions on small details of the text, the primary criterion is not the suitability of the readings in

\footnotetext{
${ }^{1}$ For criticism of this rule, see Emanuel Tov, Textual Criticism of the Hebrew Bible (Minneapolis, MN: Fortress Press, $\left.1992 /{ }^{2} 2001\right)$, 309. According to Tov, "to some extent textual evaluation cannot be bound by any rules. It is an art in the full sense of the word..." (p. 309). The emphasis on "transcriptional probability" by Karen H. Jobes and Moisés Silva, Invitation to the Septuagint (Grand Rapids, MI/Carlisle, UK: Baker Academic/Paternoster, 2000), 128-130, comes very close to my thinking.
} 
the context. Suitability is of course a necessary requirement for the reading determined to be the original, but it does not help to distinguish between several suitable alternatives, and it could also be a criterion for secondary features.

Instead, the primary criterion for text-critical decisions is the probability of what happened, the probability of the development of the alternative readings from the supposed original. For instance, if $a$ and $b$ are alternative readings in a certain case, the emergence of $b$ out of $a$, if $a$ is the original, and the emergence of $a$ out of $b$, if $b$ is the original, are often two completely different stories, and the actual decision to be made concerns which one of these stories more probably represents what really happened. In order to be able to evaluate the alternative explanations, we need to know which explanations are available, that is, what were the kinds of phenomena that took place in the various branches of the textual tradition. This is what textual history is about, and it is an essential prerequisite of textual criticism.

\section{What Happened to the Text?}

Methodological textbooks provide information on text-historical phenomena, in that they inform the student on the copying process and the kinds of unintentional changes involving confusion of certain letters and omission of words and phrases through homoioteleuton error and the like. Less attention seems to be paid to intentional changes that would go beyond such relatively harmless phenomena as harmonization with parallel passages. The traditional overall view on the textual history of the Hebrew Bible did not reckon with intentional editing of the Hebrew text in a phase that is part of the textual history. On the contrary, intentional editing was per definitionem considered to belong to a different area of study, the compositional history of the text. This overall view is still reflected in much of the text-critical argument that can be observed in exegetical literature. Meanwhile, it has become clear at least to the avant-garde of textual criticism - Julio Trebolle, no doubt, among the first ones - that the borderline between textual criticism and literary criticism cannot be drawn that sharply, in fact, that it needs to be defined anew. ${ }^{2}$

When speaking of unintentional changes during the copying process, the sources of error are very similar in all kinds of texts regardless of time, location and even language, each writing system naturally having its typical ways of confusing letters. The basic mechanisms behind the errors and, accordingly, the principles followed in textual criticism when trying to restore the original text are the same everywhere. The rules of lectio difficilior and lectio brevior give expression to very elementary tendencies that can be observed in textual transmission: a rare expression is liable to be changed to an everyday expression, and texts tend to grow in length rather than get shorter.

\footnotetext{
${ }^{2}$ Julio Trebolle emphasizes the necessity to differentiate in the history of the formation of the text between textual composition, edition, and transmission: "Textual Criticism and the Composition History of Samuel: Connections between Pericopes in 1 Samuel 1 -4," in: Archaeology of the Books of Samuel (ed. Philippe Hugo and Adrian Schenker; Supplements to Vetus Testamentum 132; Leiden/Boston: Brill 2010), 261-285 (esp. 284). For this discussion, see also idem, The Jewish Bible and the Christian Bible (Leiden: Brill, 1998), 382-387.
} 
There are however so many exceptions to these rules - errors producing difficult wordings and parablepsis shortening the text - that they really are not of much use.

Beyond the common features just mentioned, the textual history of any given text also includes features that are characteristic to this text only and not applicable to other texts. For instance, the textual history of the Septuagint is complicated by repeated approximation of its Greek text to the Hebrew text, and this is a major factor to be taken into account in textual criticism of the Septuagint. On the other hand, the textual history of the Hebrew Bible is complicated by the measures taken to establish one textual line, that is, the proto-Massoretic consonantal text, as the one and only standard text and the prevalence of this one textual line since the $1^{\text {st }}-2^{\text {nd }}$ cent. CE. As a consequence, the documentation of the textual history of the Hebrew text is fragmentary and one-sided, which naturally affects the practice of textual criticism.

\section{Characteristic Features of Textual Witnesses}

The characteristic features of textual witnesses and textual families ought to be looked for among their secondary readings, either intentional or unintentional changes of the text. While it is indeed possible to describe a textual witness as either well preserved or corrupted by the probability of unintentional errors, ${ }^{3}$ it is the kinds of intentional changes discovered in a textual witness that reveal the most characteristic features typical of this particular witness and not shared by others, unless proved otherwise. ${ }^{4}$ Such intentional features, wherever encountered, are particularly valuable for textual criticism, as they give us a clue of what can be expected of this textual witness and which explanations are available in individual cases.

In case of repeated intentional changes toward a certain direction it is justified to speak of conscious editing of the text. In such cases, it may be even possible to discern the motive behind the changes. This is where the text-critical method shows similarities with the method of Sherlock Holmes: crucial for the solution of what happened to the text is the motive behind the change. ${ }^{5}$

Now, the more practical question is where to begin. For the overall characterization, it is necessary to have evidence from the individual cases, and for the interpretation of the individual cases, an overall characterization is needed. The solution to the dilemma is to be sought in individual cases

\footnotetext{
${ }^{3}$ I agree with Emanuel Tov, Textual Criticism of the Hebrew Bible, 298-299, that such statistical probabilities should not influence the text-critical decisions in individual cases, "because exceptions... are not predictable" (299).

${ }^{4}$ This condition is often overlooked. For instance, Jürg Hutzli, Die Erzählung von Hanna und Samuel: Textkritische und literarische Analyse von 1. Samuel 1-2 unter Berücksichtigung des Kontextes (Abhandlungen zur Theologie des Alten und Neuen Testaments 89; Zürich: TVZ, 2007), 145, seems to take it for granted that all textual witnesses show signs of similar editorial measures. See also Stanley D. Walters, "Hannah and Anna: The Greek and Hebrew Texts of 1 Samuel 1," JBL 107 (1988), 385-412, who regards both the Septuagint and the MT as "discrete narratives, each with its own Tendenz." Logically, Tendenz should be attributed to secondary developments only.

${ }^{5}$ For the evidential paradigm that best describes the text-critical methodology, as it does the method of Sherlock Holmes, see Carlo Ginzburg, "Clues: Roots of an Evidential Paradigm," in: Carlo Ginzburg Clues, Myths, and the Historical Method (trans. John and Anne C. Tedeschi; Baltimore/London: The Johns Hopkins University Press, 1989), 96-125.
} 
that are complex enough to serve as key cases. The accumulation of similar cases corroborates the characterization.

In this paper, I would like to illustrate what I have said so far by examples from the story of Hannah in 1 Samuel, and through these examples, to discuss the textual character of the MT in this part of the Hebrew Bible. ${ }^{6}$ The point of comparison is mainly the Septuagint, but in several cases there are also fragments of $4 Q Q_{S a m}{ }^{a}$ available. The Septuagint was translated several centuries before the emergence of the MT as the standard text, and this means that the manuscripts of the Hebrew source text used for the translation were 200-300 years older than the starting point of the Massoretic tradition. This difference in age is significant, suggesting that readings more original than the MT will be found through the Septuagint. ${ }^{7}$ As for $4 Q Q_{S a m}{ }^{a}$, it also clearly predates the $\mathrm{MT}$, giving an authentic picture of the textual situation during the last centuries BCE. The interpretation of the evidence of the Septuagint is complicated by the fact that it is a translation, whereas the use of $4 Q Q_{S a m}{ }^{a}$ suffers from its fragmentariness. The special characteristics of these two witnesses, however, are not at the center of my discussion here.

\section{Textual Corruption in the MT}

As is well known, there are numerous smaller and larger differences between the MT, on the one hand, and the Septuagint and $4 \mathrm{QSam}^{\mathrm{a}}$, on the other, in the Books of Samuel. Theoretically speaking, it may be a question of unintentional corruption of the text in one or the other direction or it is also possible that some of these differences have their origin in deliberate editing of one or the other textual tradition. In what follows, the focus is on the textual character of the MT, and through my examples I would like to demonstrate that both corruption and deliberate editing, involving theological or ideological tendency, have taken place in the Massoretic textual tradition. How to tell the difference between intentional and unintentional changes is not always easy. Since simpler explanations should have preference, and unintentional change is a more simple explanation, this should be tried out first. But just how far can we get with this explanation?

There seems to be a fairly widespread consensus among researchers that the MT in 1 Samuel is based on a textual line that contains numerous grave errors and defects. ${ }^{8}$ Comparison with 4QSam ${ }^{a}$ and the Septuagint easily produces examples for corrupted readings in the MT:

1 Sam 1:24(-25)

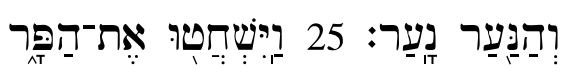

\footnotetext{
${ }^{6}$ Since it is impossible to acknowledge here all who have written on 1 Sam 1-2, I shall confine my references mainly to the more recent discussion.

${ }^{7}$ Emanuel Tov has estimated that the most important source of significant readings to be compared with the MT is the Septuagint; see Emanuel Tov, The Text-Critical Use of the Septuagint in Biblical Research (Jerusalem Biblical Studies 3; Jerusalem: Simor, 1981), 272.

${ }^{8}$ See, e.g., Julius Wellhausen, Der Text der Bücher Samuelis (Göttingen: Vandenhoeck \& Ruprecht, 1871), 1, or P. Kyle McCarter, I Samuel: A New Translation with Introduction and Commentary (AB 8; New

York/London/Toronto/Sydney/Auckland: Doubleday, 1980), 5, 8.
} 


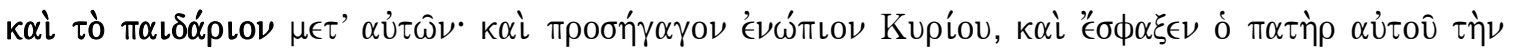

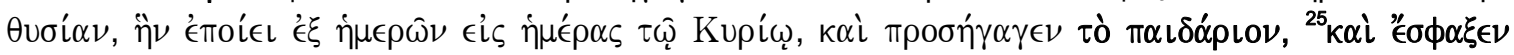

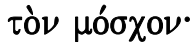

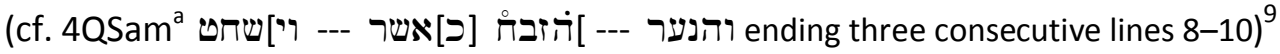

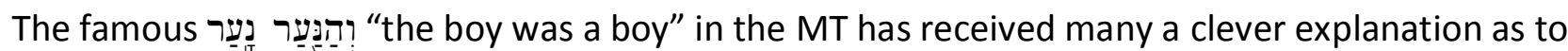
why it should be considered as the original text. ${ }^{10}$ Nevertheless, the shorter text really does not make much sense, whereas the Septuagint contains a longer description of the pilgrimage of the family, of the boy Samuel being brought to Shiloh, and of the sacrifices offered by Elkanah on this occasion, and $4 Q \mathrm{Sam}^{\mathrm{a}}$ has space enough for this. The omission cannot be explained through homoioteleuton, but it could have been a parablepsis of one long line, for instance, at the end of the first column of the book. This would presuppose a parent manuscript with fairly long lines (ca. 70 letters and spaces). At this point, $4 Q \mathrm{Sam}^{\mathrm{a}}$ shows details of the long reading at a distance of eight lines from the top of the second column, but the average line length is also clearly shorter. ${ }^{11}$ The two witnesses, the Septuagint and $4 Q \mathrm{SSam}^{\mathrm{a}}$, also agreed earlier in the same verse:

1 Sam 1:24

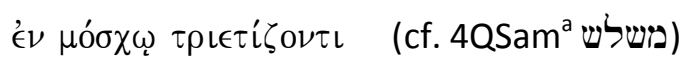

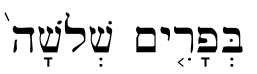

Both the Septuagint and $4 Q \mathrm{Sam}^{\mathrm{a}}$ mention a three-year-old bull as the sacrificial animal, whereas the MT is clearly exaggerated and erroneous with its three bulls. ${ }^{12}$ The MT certainly makes a more difficult reading in 1 Sam 1:24-25, but the more simple solution is not to presuppose that both the Septuagint and 4QSam ${ }^{\mathrm{a}}$ would represent secondary development.

Let us look at another, more complicated example of corruption in the MT. It is from the Song of Hannah and demonstrates that the witness of the Septuagint cannot always be interpreted straightforwardly.

\section{Sam 2:3}

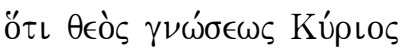

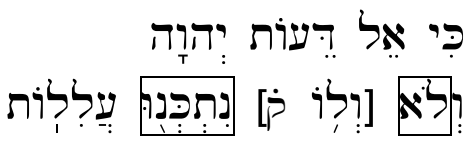

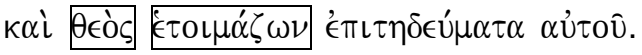

Vorlage: ואל תכן עללות (cf. 4QSamª)

NETS: "...for the Lord is a God of knowledge, and a God who prepares his own ways."13

What the MT says in the second line of this couplet is not clear: either according to the K. "deeds/works are not (לא) weighed/examined" - perhaps to be understood that God's works cannot be examined - or according to the Q. "with him (לו) works are weighed/examined" -

\footnotetext{
${ }^{9} 4$ QSam ${ }^{\mathrm{a}}$ is quoted according to Qumran Cave 4 XII · 1-2 Samuel, by Frank Moore Cross, Donald W. Parry, Richard Saley and Eugene Ulrich (DJD XVII; Oxford: Clarendon Press, 2005).

${ }^{10}$ Recently, for instance, Jürg Hutzli, Die Erzählung von Hanna und Samuel, 83-85, considered the longer text to be secondary expansion, motivated by the desire to give Elkanah a more active role in the story.

${ }^{11}$ According to Frank Moore Cross, DJD XVII, 16-17, the average width of Col. II is 45.4, and of Col. III 48.6. In addition, Col. I, which is preserved in a few tiny fragments only, seems not to have begun from the top margin (p. 28-29).

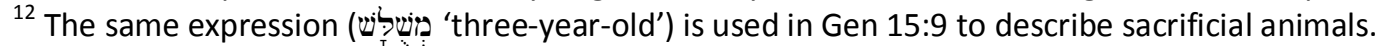

${ }^{13}$ NETS = A New English Translation of the Septuagint, ed. Albert Pietersma and Benjamin G. Wright (New York/Oxford: Oxford University Press, 2007), 1 Reigns translated by Bernard A. Taylor.
} 
referring to God as the judge who weighs human actions. In Greek both lines reveal the same pattern, describing "the Lord" as "a God" who does something: the Lord is a God who "knows" and a God who "prepares his works." It is not rare in the Hebrew Bible that the negation לא לא confused with the preposition and suffix לו (K./Q.), but the Septuagint brings into the discussion

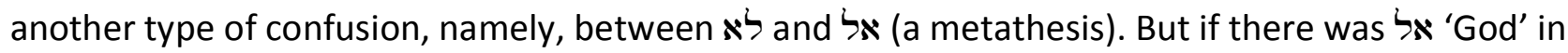
the manuscript used by the translator, the verb תכן 'to weigh, to examine' could not have appeared in nif., as in the MT (since עללות now serves as the object), but it should have been qal and most probably a participle: אל תקן עללות "a God who weighs works," which is a perfect match with the previous line. ${ }^{14}$ This is not what the Septuagint has, but it is possible to reconstruct the way the translator proceeded from this Hebrew to his translation. The verbal root תכן is fairly rare - this is the only occurrence in the Books of Samuel - and the translator may have erroneously taken it for another verb, most plausibly for the root כון (cf. 1 Sam 7:3, 13:13, 20:31, 23:22). Since the Hebrew does not explicitly say whose works are meant, the translator had the possibility of interpreting עללות as the works of the Lord. The possessive pronoun should definitely not be back-translated, which, however, has occurred in Cross's reconstruction of the Qumran manuscript (DJD XVII, p. 31). The MT is no doubt corrupt. Both K. and Q. make poor sense in the context, $\mathrm{Q}$. showing an attempt to relieve the difficulty. The initial error was perhaps the

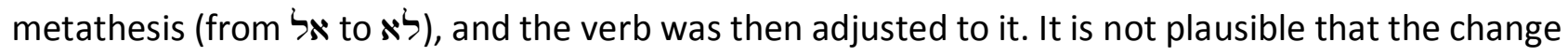
would have been altogether intentional. The recovery of the original presupposes an understanding of the character of the Septuagint and especially of the translator's deficient knowledge of Hebrew.

\section{A Puzzling Case - Corruption or Correction?}

In several cases, however, it is not easy to decide whether the MT represents a corrupted reading or a deliberate correction of the text. A much discussed example is:

1 Sam 1:23

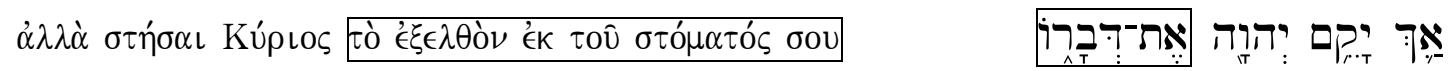

4QSama אך יקם יהו[ה היוצא מפיך]

NETS : “Only, may the Lord establish that which goes out of your mouth."

The alternative readings are quite disproportionate. It is impossible to think that one of the readings would have come about through confusion of letters or any other normal error. The reference to a vow ("what has come out of your mouth"), represented by the Septuagint and $4 Q \mathrm{Sam}^{\mathrm{a}}$, is the reading that makes the best sense in the context, whereas no mention has been made of a word of the Lord that could be fulfilled. Hannah has made a vow, and her husband, hearing about the vow for the first time, confirms that it should be fulfilled ("only may the Lord

\footnotetext{
${ }^{14}$ This solution was already offered by Julius Wellhausen, Der Text der Bücher Samuelis, 43. Cf. also Prov 16:2, 21:2, 24:12. - Cf. the reconstruction of $4 Q$ Sam $^{\text {a }}$ by Cross (DJD XVII, 31).
} 
confirm your vow"). ${ }^{15}$ This is of course perfectly in accordance with the law concerning vows made by women (cf. Num 30:11-16). One of the solutions offered to this case is that the Septuagint or its Vorlage - together with $4 Q Q_{S a m}{ }^{\text {a }}$ - would represent a deliberate, "nomistic" correction motivated by the desire to bring the text into accord with the Law (Num 30). ${ }^{16}$ This correction should have happened very early to end up in the Septuagint. Furthermore, one cannot help asking why then did this correction not use the exact terminology of the law in Num

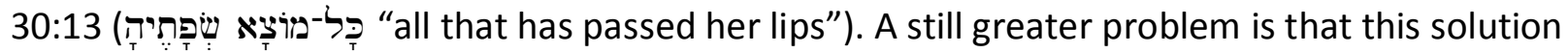
would have severe consequences, because it creates a close affiliation between the Vorlage of the Septuagint and $4 \mathrm{QSam}{ }^{\mathrm{a}}$, for which no clear evidence has otherwise been found. ${ }^{17}$

Quite the opposite, a change by corruption in the MT was suggested by Bo Johnson, who designed a theory to explain the numerous irregular textual differences in 1 Sam 1-2, differences that are unexplainable by the normal rules. He suggested that one parent manuscript of the MT had been badly damaged in the beginning of the scroll, for the simple reason that rolling a scroll back and forth while reading had a stronger wearing effect on the edge of the scroll. Bo Johnson thought that one parent manuscript of the MT must have been so badly damaged that it had holes in it and that the next scribe simply had to fill in the gaps out of his memory or imagination and thus happened to fill in details that did not belong there. ${ }^{18}$ This of course solves all the problems at once.

Presupposing that the expression "what has come out of your mouth" was erased from a parent manuscript of the MT, one could explain that a subsequent scribe tried to complement the text on the basis of the verb קif., which frequently occurs, with Yahweh as its subject, in reference to the fulfilment of the divine word (1 Kings 2:4, 6:12, 8:20, 12:15; 2 Kings 23:3, 24). I must confess that for a long time I was content with this explanation. I was not particularly eager to find ideological changes in the MT, but rather tried to look for natural reasons, which should of course, out of methodological considerations, be given priority before more complicated explanations.

That we are here dealing with a case almost beyond the capacity of a textual critic is shown by the solution offered to this very same problem by Emanuel Tov, who suggested that both readings

\footnotetext{
${ }^{15}$ Cf. Jürg Hutzli, Die Erzählung von Hanna und Samuel, 79; Hutzli's interpretation that Elkanah did not confirm Hannah's vow, but instead left it for Yahweh to confirm, is unnatural. In connection with vows (Num 30), קום occurs, not only in hi. (cf. Hutzli's argument), but more often in qal in the meaning 'stand,' 'be valid,' and in relation to this hi. can be interpreted as 'consider to be valid' as well as 'confirm.' By saying that "Yahweh should consider her vow to be valid" (קום hi.), Elkanah in actual fact confirms (קום hi.) his wife's vow.

${ }^{16}$ Alexander Rofé, "The Nomistic Correction in Biblical Manuscripts and its Occurrence in 4QSam," Revue de Qumran 14 (1989), 247-254.

${ }^{17}$ See Emanuel Tov, "The Contribution of the Qumran Scrolls to the Understanding of the LXX," in: Septuagint, Scrolls and Cognate Writings (ed. G.J. Brooke and B. Lindars; SCS 33; Atlanta, GA: Scholars Press, 1992), 11-47, esp. 25.

${ }^{18}$ Bo Johnson, "On the Masoretic Text at the Beginning of the First Book of Samuel," Svensk Exegetisk Årsbok 41-42 (1976-77), 130-137.
} 
"may be considered alternative and could be equally original" - that is, leaving the question open. $^{19}$

\section{Deliberate Changes of the Text in the MT}

Of all the theoretical alternatives, the possibility of a deliberate, ideological change in the MT - to leave out a reference to the vow of a woman - should also be considered. ${ }^{20}$ After the development in textual studies during our post-Qumran era, I think we are better prepared than the previous generation was to accept solutions that presuppose deliberate change of the text, particularly in the MT.

Now, decisions in cases like the one at hand presuppose familiarity with the textual witness in question and a notion of what can be expected from this witness. In the recent discussion on the Hebrew text of the Books of Samuel, more and more cases of deliberate changes out of theological or ideological motives have been discovered, not only in my own work but even more so by others. ${ }^{21}$ This has induced me to look again at the textual problems in the story of Hannah. Finding indisputable examples of deliberate change would mean that the dominoes start falling in the other direction.

At a closer look, the following examples are fairly obvious. The first chapter of 1 Samuel reveals omissions of two sentences referring to Hannah's prayer: in v. 9 according to the Septuagint, Hannah "stood before the Lord" praying for a son, and in v. 14 Eli told her "to go away from before the Lord." Both sentences have no equivalent in the MT.

1 Sam 1:9

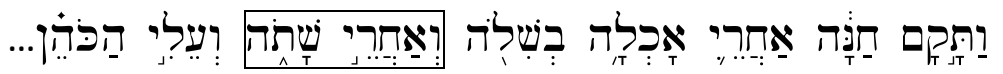

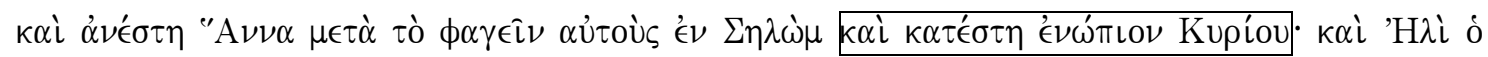

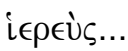

Vorlage: ותתיצב לפני יהוה

NETS: “And [Hannah rose] after they had eaten at Selo, and stood before the Lord and Eli the priest...

1 Sam 1:14

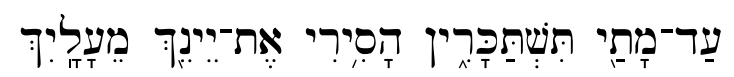

\footnotetext{
${ }^{19}$ Emanuel Tov, Textual Criticism of the Hebrew Bible (Minneapolis, MN: Fortress Press, 1992/ ${ }^{2} 2001$ ), 176: "to all appearances, these readings may be considered alternative and could be equally original... According to a different train of thought, however, only one reading was original... Although it seems impossible to decide between these two readings, our inability to decide should not undermine the probability of the assumption that one of the two readings was contained in the original text... Alternatively, it is equally possible that another, third, reading (such as דברך, "your word," probably presupposed by $\mathbf{5}$ ) was contained in the original text..."

${ }^{20}$ According to Jürg Hutzli, Die Erzählung von Hanna und Samuel, 146, 271, the editor of the MT was motivated by the desire to emphasize God's sovereign action as opposite to human action (v. 23).

${ }^{21}$ Of Julio Trebolle's many publications in this area of study I would just like to refer to Centena in libros Samuelis et Regum (Textos y estudios "Cardenal Cisneros" 47; Madrid: CSIC, 1989). For variant literary editions, see Eugene Ulrich, The Dead Sea Scrolls and the Origins of the Bible (Grand Rapids, MI/Cambridge, UK: Eerdmans, 1999), 106-110, esp. on the Books of Samuel 65-68. See also my "Lost in Reconstruction? On Hebrew and Greek Reconstructions in 2 Sam 24," in: Bulletin of the International Organization for Septuagint and Cognate Studies 40 (2007), 89-106, in which I discuss, among other things, the repeated omission in the MT of 2 Sam 24 of expressions for David choosing - in accordance with Yahweh's instructions - between the three different consequences of the census.
} 


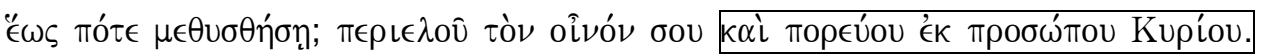

Vorlage: ולכי מלפני יהוה

NETS: "How long will you be drunk? Put away your wine and go out from the presence of the Lord.".

If an omission like this were to happen only once, it could be regarded as an accident, even if an explanation through homoioteleuton does not work. Having the same accident occur twice requires some effort. It seems that the MT has deliberately removed Hannah from the presence of the Lord, as if a woman could not stand before the Lord to pray and to make a vow. ${ }^{22}$ This is, however, not the only difference between the witnesses in 1 Sam 1:9. There is also an addition in the MT in v. 9: "and after drinking" added to "after eating." The Septuagint also presupposes a 3.m.pl. suffix, which is actually grammatically indispensable in Hebrew: אחרי אכלם בשלה "after they had eaten in Shiloh." The addition betrays its secondary status by its peculiar construction with an infinitive absolute שָׁתה, to which the other infinitive has been adjusted, and its location after "in Shiloh." This is nothing else but a wicked suggestion that Eli was right after all in suspecting Hannah of being drunk (v. 14), and it shows that the two verses have been compared and harmonized with each other.

Looking more closely into the details of the story, more and more features come up, revealing the same pattern. ${ }^{23}$ The following is a further case to be considered, one that cannot be found in our standard editions, but only in the apparatus of the major Cambridge edition by Brooke-McLeanThackeray:

\section{Sam 1:13}

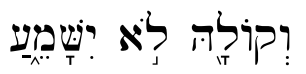

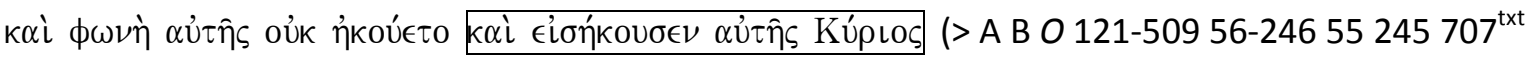
Aeth $\mathrm{Sa}=\mathfrak{2} \mathfrak{i} \mathrm{Ra}$ Compl)

Vorlage: וישישמע אליה יהוה / וישמעה יהוה

"...and her voice was not heard, but the Lord heard her."

The combination of Greek witnesses leaving out this sentence includes mss that have proved to contain sporadic approximations to the Hebrew text, ${ }^{25}$ practically the Massoretic consonantal

\footnotetext{
${ }^{22}$ Similarly Jürg Hutzli, Die Erzählung von Hanna und Samuel, 15, 145-146, who connects the two mentioned cases with two further cases also lacking "before the Lord" in the MT, namely 1 Sam 1:11 (Hannah's vow) and 2:11 (Samuel being left in Shiloh); however, according to Hutzli, the motive behind these changes in the MT was cult-theological and thus gender-neutral.

${ }^{23}$ One such example may be "here am I" occurring in the Septuagint of 1 Sam 1:8. Donald W. Parry, "Hannah in the Presence of the Lord," in: Archaeology of the Books of Samuel (ed. Philippe Hugo and Adrian Schenker; Supplements to Vetus Testamentum 132; Leiden/Boston: Brill 2010), 53-73, pays attention to the fact that "here am I" is elsewhere never spoken by a woman; after discussing many of the cases discussed in the present paper, Parry concludes that they cannot be explained as scribal errors, but he is not explicit about where he finds the ideological and theological readings.

${ }^{24}$ The Hebrew verb שמע can be construed with an object or with different prepositions, but in the majority of cases the translator of 1 Samuel employed the genitive. In reference to a person both an object and the preposition אל אל he been used, e.g. Ex 6:12 (both constructions parallel to each other).

${ }^{25}$ Sporadic early approximations to the Hebrew are found in the B text, i.e. B 121-509 Aeth, often accompanied by A and $O(=247-376)$ as well as some other mss; see my "A Kingdom at Stake," in: Scripture in Transition: Essays on
} 
text, and thus it seems clear to me that the sentence did belong to the original wording of the Septuagint and should have its place in the main text of the critical Samuel edition. Furthermore, it was translated from the Hebrew source text used by the translator and not added in its Greek form. ${ }^{26}$ However, whether this sentence can be regarded as part of the original Hebrew text is a question that must be dealt with separately. The first impression is that it is a pious addition, but on the other hand, where do we have an "original text" of the Hebrew Bible that would not have secondary additions? The Dtr History, in particular, is a composition that has brought together different traditions and sources and has been heavily edited. The crucial question in our case is whether this sentence was just a sporadic addition in one branch of the textual tradition or part of the text from early on, having been deliberately erased from the $\mathrm{MT} .{ }^{27}$ The argument for the longer text can only be based on a thorough acquaintance with the textual tradition in question and the probability of ideological omissions in it.

There is one more example concerning Hannah's actions within the sanctuary that reveals differences between the Septuagint and the MT.

1 Sam 1:18

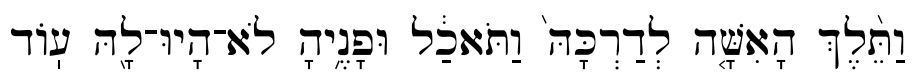

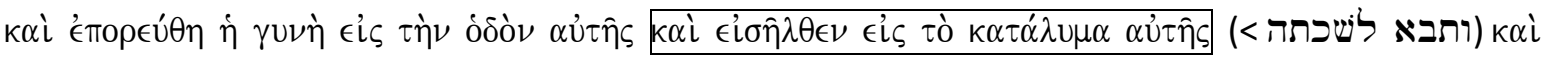

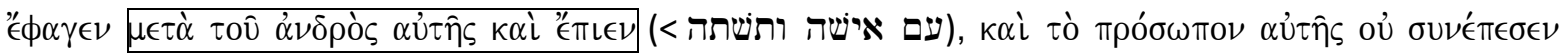

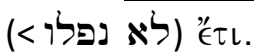

NETS: "And the woman went on her way and entered her quarters and ate and drank with her husband, and her countenance was sad no longer."

After the prayer and the encounter with Eli, Hannah returns to the dinner table and continues the meal with her husband and obviously with the rest of the family. Again, there is one whole sentence and some further details in the Septuagint that are lacking in the MT. The Septuagint

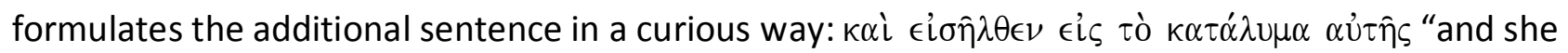
entered her guest room," but there is a further occurrence of the fairly rare word $\kappa \alpha \tau \alpha \dot{\alpha} \lambda u \mu \alpha$ in 1 Sam 9:22 where it renders לִשְָָָּׁה, an equally rare Hebrew word meaning 'a hall (for a sacrificial

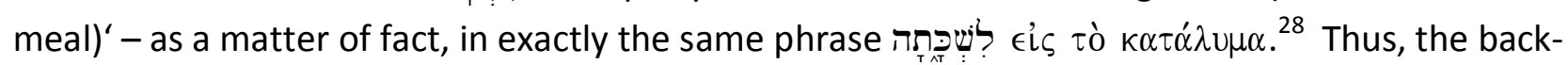

Septuagint, Hebrew Bible, and Dead Sea Scrolls in Honour of Raija Sollamo (ed. A. Voitila and J. Jokiranta; SJSJ 126. Leiden: Brill, 2008), 353-366.

${ }^{26}$ A close parallel to our case is found in Gen 30:22 וישמע אליה אלהים, which relates how Rachel's childlessness was ended and this may have inspired the remark in the case of Hannah. It is, however, not probable that the borrowing

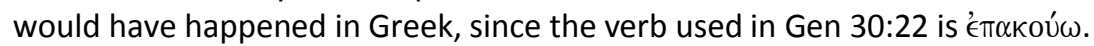

${ }^{27}$ A further parallel that fits the pattern described above comes to my mind: in Hannah's Psalm 1 Sam 2:9 the Septuagint and 4QSam ${ }^{a}$ have a couplet lacking in the MT: "He grants the prayer to the one who makes a vow and blesses the years of the righteous." Instead the MT reads: "For the pillars of the earth are the Lord's, and he set the world on them. He keeps the feet of his faithful ones, but the wicked are silenced in darkness." See my article "Hannah's Psalm: Text, Composition, and Redaction," in Houses Full of All Good Things: Essays in Memory of Timo Veijola, ed. J. Pakkala and M. Nissinen (Publications of the Finnish Exegetical Society 95; Helsinki: The Finnish Exegetical Society/Göttingen: Vandenhoeck \& Ruprecht, 2008), 354-376.

${ }^{28}$ At 1 Sam 1:18 the translator seems to have interpreted the final $\mathrm{N}$ (in fact, ה locale) as a suffix of the $3^{\text {rd }}$ person f.sg., which should not be back-translated. Cf. 1 Sam 2:3 above. 
translation from Greek to Hebrew is evident and makes good sense in the context. ${ }^{29}$ Hannah returns to that part of the sanctuary where the sacrificial meal takes place, and this time the Septuagint mentions drinking and merry-making along with eating. The MT probably reveals a case of corruption at the end of the verse where the original seems to have employed the idiom נפל + + suffix 'to look sad/distressed' (cf. Gen 4:5,6).

It looks as if we have here a few more pieces of the very same puzzle we have been sketching: the MT leaves out "drinking," which had been moved to the beginning of the story (v. 9), as well as the reference to one part of the sanctuary, which may be connected with the removal of the two sentences mentioning "Hannah standing before the Lord" (vv. 9 and 14) or else be motivated by a general idea that women could not take part in sacrificial meals at the sanctuary. With the short expression "went her way" and the omission of "with her husband" as well as "drinking," the MT seems to hint that Hannah did not return to the dining hall to eat and that the sacrificial meal was already over.

\section{Motivation behind the Changes}

To return to 1 Sam 1:23, if Hannah - according to the MT - was not standing before the Lord, and was in fact drunk, there is no reason to speak of a vow that she had made to the Lord. There seems to be a whole network of editorial corrections that change the picture of Hannah and her son. ${ }^{30}$ Whatever became of the son, Samuel, his mother's vows played no part in it. According to the MT, Hannah in fact made no legitimate vow before the Lord. This is the motivation behind the change in 1 Sam 1:23, the case we started from. Decisive for Samuel's calling was the word of the Lord and not a vow by his mother.

This raises a further question about the references to Naziriteship. If the MT connects Samuel's calling with the word of the Lord, and thus primarily with prophecy, and if Hannah did not speak a vow before the Lord, then there is no reason to connect the promises Hannah had made on behalf of her unborn son with Naziriteship. The MT again removes the word לפניך and with it the address to the Lord as well as one of the characteristic signs of a Nazirite, namely abstinence.

1 Sam 1:11

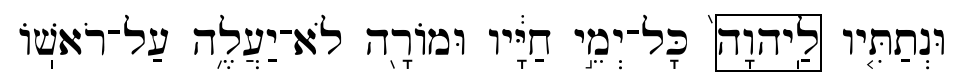

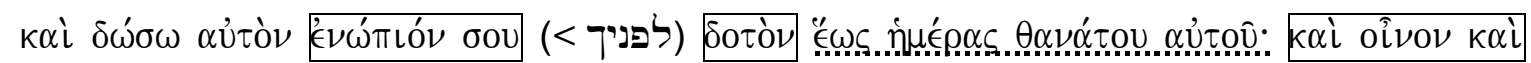

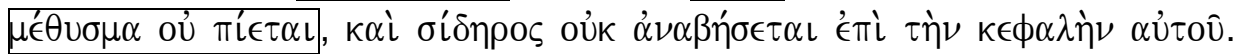

NETS: "and I will give him as one devoted before you until the day of his death; and wine nor strong drink he shall not drink, and no iron shall come upon his head"

\footnotetext{
${ }^{29}$ Nevertheless, Jürg Hutzli, Die Erzählung von Hanna und Samuel, 72, prefers another back-translation, which he then regards as a secondary feature of the Hebrew Vorlage of the Septuagint. As a matter of fact, the tendencies recognized by Hutzli in the MT (Hannah's actions being relativized) and in the LXX (emphasis on Elkanah's actions) are like two sides of one and the same coin.

${ }^{30}$ Jürg Hutzli, Die Erzählungen von Hanna und Samuel, 79-80, discusses the same cases but does not see the connection between them as I do; consequently, he also describes the theological motivations differently.
} 
The word Nazirite is made explicit in $4 Q \mathrm{SSam}^{\mathrm{a}}$ in v. 22 (ונת[תיהו נזיר). It does not however appear in the Septuagint, but instead there is one small word in v. 11 that lacks a correspondence in the MT,

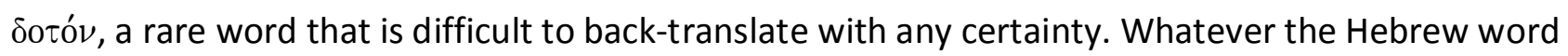
in the Vorlage, whether ניר נr some other word, it refers to the status of the unborn son as a consequence of the mother's vow, and it is absent from the MT. ${ }^{31}$

\section{Conclusion}

Thus, the MT can be observed to contain both corruption and correction. In the story of Hannah, it reveals fairly massive, although not fully consistent, editorial measures, which aimed at polishing the text by removing details that may have been considered doubtful from a theological, religiousconservative or even sexist viewpoint. ${ }^{32}$

The examples that I have given reveal just a small sample of this late editorial layer, which can be observed in other parts of the Books of Samuel as well. Most of the changes made in the MT seem to have a theological or ideological motivation, but the individual changes are often so small that the nature of this activity only becomes clear through the accumulation of a number of changes with a similar aim or changes showing a connection to one another.

Exact dating of this editorial activity is impossible, but in order to have left features of the older edition in the Septuagint and in $4 Q \mathrm{SSam}^{\mathrm{a}}$ untouched, it must be fairly late. It must be a question of the time around the turn of the era, perhaps the $1^{\text {st }}$ century BCE. This means that the Books of Samuel - and probably the Dtr History in general - was not yet considered to be "canonical" in the sense of being sacred Scripture and being authoritative and unchangeable in its wording. My suggestion is that the editorial polishing of these books was felt to be necessary precisely for their preparation to be included in the collection of the Prophets and thus in the "canon" of sacred Scripture.

\footnotetext{
${ }^{31}$ P. Kyle McCarter, I Samuel, 60-61, considers the features connected with Naziriteship to be original, although having a prehistory connected with Saul (p. 65).

${ }^{32}$ Cf. Eugene Ulrich, The Dead Sea Scrolls and the Origins of the Bible, 67, rephrasing Stanley D. Walters's statement (cf. n. 4 above): “... in 1 Samuel 1 the MT and the LXX (in basic fidelity to its Hebrew Vorlage) may well present two different editions of the text, one intentionally different from the other, each internally consistent."
} 